\title{
The Routledge Handbook of English as a Lingua Franca
}

\section{Edited by Jennifer Jenkins, Martin J. Dewey and Will Baker}

\section{Series: Routledge Handbooks in Applied Linguistics}

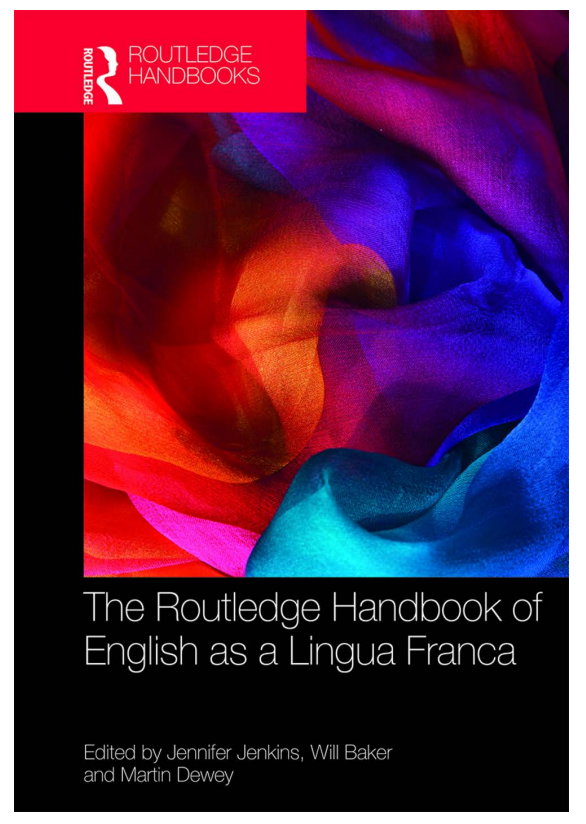

The Routledge Handbook of English as a Lingua Franca (ELF) provides an accessible, authoritative and comprehensive introduction to the main theories, concepts, contexts and applications of this rapidly developing field of study.

Including 47 state-of-the art chapters from leading international scholars, the handbook covers key concepts, regional spread, linguistic features and communication processes, domains and functions, ELF in academia, ELF and pedagogy and future trends.

This handbook is key reading for all those engaged in the study and research of English as a Lingua Franca as well as Global Englishes more broadly, within the fields of English language, Applied Linguistics, and Education.

August 2017 - 784 pages

HB: 978-1-138-85532-8

$£ 165.00 / \$ 225.00$

\section{Editors}

Jennifer Jenkins is Chair Professor of Global Englishes at the University of Southampton and founding Director of the University's Centre for Global Englishes. She is also founding co-editor of the book series, Developments in English as a Lingua Franca (De Gruyter Mouton).

Martin J. Dewey is Senior Lecturer in Applied Linguistics at King's College London.

Will Baker is Lecturer in Modern Languages at the University of Southampton. He is Deputy Director of the University's Centre for Global Englishes and convenor of the MA programme in Global Englishes. He is also co-editor of the De Gruyter Mouton book series, Developments in English as a Lingua Franca. 


\section{Table of Contents}

Introduction to the volume

\section{Part One: Conceptualising and positioning ELF}

1. Conceptualising ELF - Anna Mauranen

2. English as a lingua franca and intercultural communication - Will Baker

3. Communities of practice and English as a lingua franca - Susanne Ehrenreich

4. Complexity and ELF - Diane Larsen-Freeman

5. English language teaching: pedagogic reconnection with the social dimension - Constant Leung and Jo Lewkowicz

6. Cognitive perspectives on English as a lingua franca - Christopher Hall

7. Standard English and the dynamics of ELF variation - Barbara Seidlhofer

8. Historical perspectives on ELF - H. G. Widdowson

\section{Part Two: Regional spread of ELF}

1. ELF and the EU/wider Europe - Tamah Sherman

2. English as a lingua franca in the Gulf Cooperation

Council states - Nuha Alharbi

3. The development of English as a lingua franca in ASEAN - Andy Kirkpatrick

4. Chinese English as a lingua franca: an ideological inquiry - Ying Wang

5. The status of ELF in Japan - James D'Angelo

6. ELF in Brazil: recent developments and further directions - Telma Gimenez, Michele Salles El Kadri and Luciana Cabrini Simões Calvo

7. Is English the lingua franca of South Africa? - Christa van der Walt and Rinelle Evans

\section{Part Three: ELF characteristics and processes}

1. Analysing ELF variability - Ruth Osimk-Teasdale

2. The pragmatics of ELF - Alessia Cogo and Juliane House

3. Pronunciation and miscommunication in ELF interactions: an analysis of initial clusters - Ishamina

Althirah Gardiner and David Deterding

4. Creativity, idioms and metaphorical language in ELF - Marie-Luise Pitzl

5. Grammar in ELF - Elina Ranta

6. Morphosyntactic variation in spoken English as a lingua franca interactions: revisiting linguistic variety Beyza Björkman

7. Language norms in ELF - Niina Hynninen and Anna Solin

8. Uncooperative lingua franca encounters -

Christopher Jenks

\section{Part Four: Contemporary domains and functions}

1. Translingual practice and ELF - Suresh Canagarajah and Daisuke Kimura

2. ELF in the domain of business - BELF: what does the B stand for? - Anne Kankaanranta and Leena Louhiala-Salminen

3. ELF in social contexts - Kaisa S. Pietikäinen

4. Humour in ELF interaction: a powerful, multifunctional resource in relational practice - Patricia Pullin

5. ELF in electronically mediated intercultural communication Chittima Sangiamchit

6. ELF and multilingualism - Alessia Cogo

7. ELF and translation/interpreting - Michaela Albl-Mikasa

\section{Part Five: ELF in Academia}

1. Beyond monolingualism in higher education: a language policy account - Ute Smit

2. EMI in higher education: an ELF perspective - Kumiko Murata and Masakazu lino

3. Written academic English as a lingua franca - Bruce Horner

4. Transforming higher education and literacy policies: the contribution of ELF - Ursula Wingate

\section{Part Six: ELF and Pedagogy}

1. ELF and teacher education - Martin Dewey and Laura Patsko

2. ELF-aware teaching, learning and teacher development - Nicos Sifakis and Yasemin Bayyurt

3. ELF and ELT teaching materials - Nicola Galloway

4. ELF and content and language integrated learning - Julia Hüttner

5. ELT and ELF in the East Asian contexts - Ayako Suzuki, Haibo Liu and Melissa $\mathrm{H}$. $\mathrm{Yu}$

6. Language as system and language as dialogic creativity: the difficulties of teaching English as a lingua franca in the classroom Sue Wright and Lin Zheng

7. English Language teachers and ELF - Enric Llurda

Part Seven: ELF into the future: trends, debates, predictions

1. English as a lingua franca: changing 'attitudes' - Robert Baird and Mariko Baird

2. ELF in migration - Maria Grazia Guido

3. Global languages and lingua franca communication - Sonia Morán Panero

4. Language assessment: the challenge of ELF - Luke Harding and Tim McNamara

5. ELF and critical language testing - Elana Shohamy

6. The future of English as a lingua franca? - Jennifer Jenkins Index 